\title{
Ambiente Construído Assistencial e Promoção da Humanização no Procedimentos de Saúde.
}

\author{
Castro, Jorge Azevedo de; Rodrigues, Helena \\ Uff — jorgecastro55@fiocruz.br
}

Introdução: os hospitais universitários são estruturas de ensino e assistência não só voltados para a formação em saúde, mas também para a arquitetura hospitalar e engenharia clínica, que trabalham aspectos de humanização complementares aos procedimentos clínicos dentro de normas técnicas e legislação específica; Objetivos: iniciar um processo de humanização do ambiente construído hospitalar em larga escala com o reconhecimento da visão de profissionais e pacientes que usam espaços e equipamentos integrados por projetos de arquitetura e engenharia que possam ser avaliados para adequação a novas demandas e tecnologias ao longo do ciclo de vida útil, bem como visando documentar essa experiência para novos projetos; métodos: a metodologia de avaliação pós ocupação do ambiente assistencial gera informações técnicas e nova bisão do ambiente em uso; Resultados: a avaliação aplicada ao caso do Hospital Universitário da Universidade Federal Fluminense serviu como base para um Plano de Obras e Manutenção voltados para humanização do ambiente, bem como tornouse base da disciplina de Arquitetura e Saúde na graduação e pós-graduação na mesma universidade; Conclusões: os planos de requalificação baseados nas avaliações de ocupação são um caminho seguro para os gestores dos serviços e da infraestrutura assistencial de saúde, segundo parâmetros técnicos e humanitários confirmados pelos usuários desses espaços edificados.

Castro, Jorge Azevedo de; Rodrigues, Helena. Ambiente Construído Assistencial e Promoção da Humanização no Procedimentos de Saúde.. In: Anais do Congresso Internacional de Humanidades \& Humanização em Saúde [= Blucher Medical Proceedings, num.2, vol.1]. São Paulo: Editora Blucher, 2014. ISSN 2357-7282

DOI 10.5151/medpro-cihhs-10401 